червень, 2019 p.

биологическом материале. Проводилось причинение повреждений при условии плотного контакта электродов электрошокового устройства с кожей и при условии возникновения искрового разряда при нахождении электродов электрошокового устройства на расстоянии 0,5-1см от кожи. В ходе проведения эксперимента установлено, что при условии плотного контакта между электродами и кожей макроскопически видимые повреждения не образовывались. При условии причинения повреждений при нахождении электродов на расстоянии 0,5-1см от кожи возникали парные повреждения, расположение которых в целом соответствовало расположени. электродов электрошокового устройства.

Ключевые слова: судебная медицина, электрошоковые устройства, электрометка.

\title{
EXPERIMENTAL STUDY OF INJURIES CAUSED BY CONTACT ELECTRIC SHOCK WEAPON, DEPENDING ON THE DISTANCE AND TIME OF IMPACT
}

\section{Varfolomeiev Y.A.}

Abstract: An experiment was conducted on causing injuries by two models of stun guns on the biological material. Injuries was carried out under the condition that the electrodes of the electroshock device is in tight contact with the skin and under the condition that a spark discharge occurs when the electrodes of the electroshock device are located at a distance of $0.5-1 \mathrm{~cm}$ from the skin. In the course of the experiment, it was established that, under the condition of tight contact between the electrodes and the skin, macroscopically visible injuries was not formed. In the case when the electrodes were located at a distance of $0.5-1 \mathrm{~cm}$ from the skin, paired injuries occurred, the location of which generally corresponded to the location of the electrodes of the stun gun.

Keywords: forensic medicine, stun gun, electric burn.

УДК 612.12-001.45:340.624

\section{MECHANISM OF FORMATION OF ROTARY COMPACT LAYER CHIPPING AT THE EDGES OF THE GUNSHOT FRACTURE OF FLAT BONES}

\author{
CMikhaylenko O.
}

\author{
Kiev City Clinical Bureau of Legal Medicine doctorant postgraduate student of the Department of \\ Forensic Medicine of P.L. Shupyk National Medical Academy \\ of Postgraduate Education
}

Relevance.

There are significant number of forensic scientific works dedicated to the morphological features of gunshot injuries, both on different parts of the body and various human tissues. In the treatise described specific marks and morphological features of injuries, which allow to establish the shot distance, number and sequence of wounds, shot direction etc [1, 2, 3, 4, $5]$.

Gunshot injuries of bone tissue were also studied by many authors. They explained and proposed the mechanisms of formation of perforated gunshot fractures of both flat and tubular bones $[5,6,7,8]$. The authors explain the formation of radiating fractures of external bone plate around the gunshot perforating bone wound by an external bend of bone sector bounded by the radial fractures. They justify their opinion with the acute-angled and oblique edge of the fracture on the outer plate and the rectangular edge of the circular fractures on the inner compact plate, which is possible with the expansion of the cranial cavity due to the hydrodynamic effect.

However, during the scientific research, forensic specialists considered only the translation movement of the gunshot projectile. The widely known fact about great angular velocity of spin the bullet around the longitudinal axis which is achieved through the helical groove patterns inside the gun barrel for flying bullet stabilization was not taken into attention. At the same time the spinning velocity of bullets fired from some modern rifles and automatic weapons has a significant magnitude. For example, the spin velocity of bullets from some of modern cartridges is as follow: bullet from cartridge 7,62x54 R (Russia) at the initial bullet velocity $830 \mathrm{~m} / \mathrm{s}$ has a rotational speed $3458 \mathrm{r} / \mathrm{s}$; bullet from cartridge 5,45x38 7H6 (Russia) at the initial bullet velocity $900 \mathrm{~m} / \mathrm{s}$ has a rotational speed $4500 \mathrm{r} / \mathrm{s}$; bullet from cartridge 5,56x45 M193 (USA) at the initial bullet velocity $990 \mathrm{~m} / \mathrm{s}$ has a rotational speed $3245 \mathrm{r} / \mathrm{s}$; bullet from cartridge 5,56x45 M855 (USA) at the initial bullet velocity $915 \mathrm{~m} / \mathrm{s}$ has a rotational speed $5140 \mathrm{r} / \mathrm{s}$.

Thus, in addition to the translation movement gunshot projectile also has a very significant rotation velocity, which will lead to morphological changes in the damaged material.

The purpose of this research was the study of the process of destruction of flat bones and the formation of rota- tional cleavages along the edge of fractures in the case of a gunshot injuries caused by a rifle shot.

Research material.

Twenty original injuries taken from the archive of Kiev City Clinical Bureau of Legal Medicine were studied during the scientific research. Injuries of flat bones with reliably known data about the weapons from which the shots were fired were 
selected. In the experiment 40 injuries of flat bones caused by the shots from 4 samples of weapons in a series of 10 shots were obtained. As a weapon, due to the aim of the study, models of one caliber were used, but having different (right and left) direction of the slope of barrel channel rifles. The distance from which the shots were fired was 5 meters.

\section{Methods of research.}

Visual, analytical, comparative methods of the research were used. To evaluate the process of the destruction of a flat bone, we used data and methods from theoretical mechanics. The process of destruction under the influence of a hemispherical projectile was described earlier [9].

\section{Results of research.}

On the first stage of the experiment we simulated the interaction of a firearm projectile with a flat bone using the finite element method of analysis. In the three-dimensional virtual space, two models were created. Model of a flat bone was made in the form of a flat plate with a facet length $100 \mathrm{~mm}$ and thickness $5 \mathrm{~mm}$. Strength characteristics are as a fol- lowing: structural robustness of bone material $1,02 \mathrm{~g} / \mathrm{cm}^{2}$; Poisson's ratio 0,2 ; elastic modulus $1,38 \bullet 10^{3} \mathrm{~kg} / \mathrm{mm}^{2}$ [8]. The projectile was made in accordance with the original dimensions of the bullet to the cartridge 9x18 mm. Strength charac- teristics of metals were taken from internal library Inventor Professional.

Under program conditions the models of the projectile were able to shift in the perpendicular direction to the model of the bone, which corresponded to $100 \mathrm{~mm}$ relative to $\mathrm{Z}$ axis. In the relation to other axis ( $\mathrm{X}$ and $\mathrm{Y}$ ) the offset was 0 . The model of the bone was rigidly fixed along the lateral faces, thus its shift was 0 . The projectile contacted with the model of the bone in the correspondence to the contact position indicated in the software as a "separation without slipping". The force was applied to the bottom of the bullet as a pressure $1 \mathrm{mPa}$, which caused the uniform distribution of the load across the facet and corresponded to the load during the shot from a pistol. An additional load was applied to the bullet body in the form of a torque equal to $1000 \mathrm{~N} \cdot \mathrm{m}$.

The result of deformations and tensions simulation (evaluation by Mises) is presented as an area of colour changes of the studied physical system of tension fields. Thus, the blue colour indicate the areas with no tensions and the red color is the zones with maximal ("critical") tensions lead to the destruction of material.

As a result of the simulation the data were obtained indicating the unevenness of the tensions along the edges of the place where the projectile was inserted into the plate in the form of propeller blades twisted in the course of rotation of the projectile (picture 1).

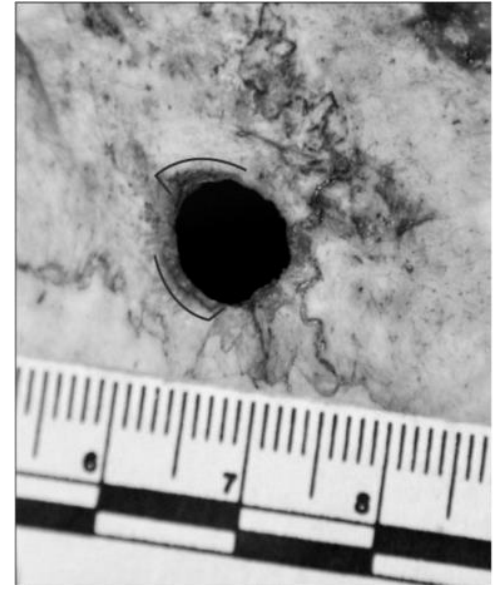

a

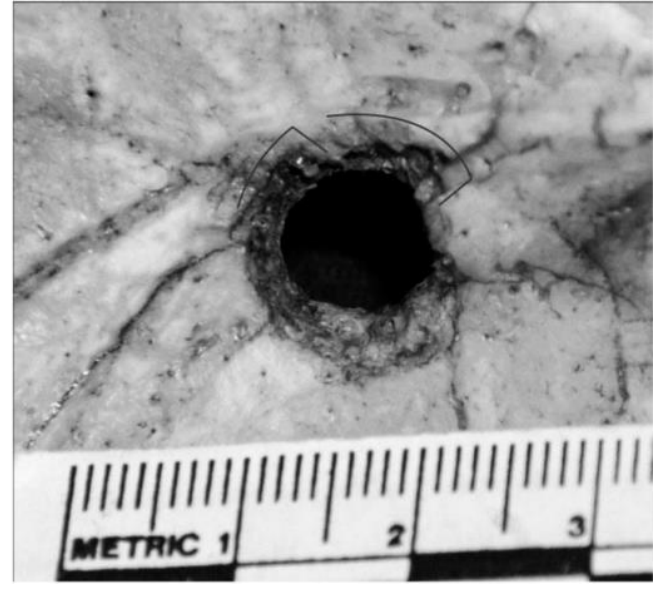

b

Picture 1. Chips on the edge of the gunshot fracture, formed by a pistol shot with right riffles from the side of the outer bone plate (a) and from the inner bone plate (b).

On the back side of the plate, at the point of exit of the projectile (in the case of penetration of the plate), irregular fields of the tensions in the form of turbine blades opened in the opposite direction from the direction of rotation of the projectile were observed.

When studying gunshot fractures of the bones of the skullcap, it was revealed that along the edge of the defect in bone tissue there is uneven shattering of the compact layer of the bone both in the inlet and outlet openings.

Morphology of the chips which indicate the direction of the bullet rotation was more pronounced from the side of the inner bone plate due to the volume of the chipping, which is typical for the output of gunshot injury.

The researches performed give an explanation to the mechanism of formation of a gunshot injury of flat bone. At the moment of the contact of the firearm projectile with the bone tissue, the angular velocity of the projectile rotation is transferred to the damaged material. Particles of the material being destroyed, which are located in an inflow zone $[9,10]$ correspond to the area of the formation of the ring-shaped bone cracks, acquire an angular acceleration and begin to shift toward the rotation of the firearm projectile. The transfer of angular velocity from the projectile to the damaged bone tissue occurs as long as the head of the projectile experiences a frontal resistance, and the damaged bone 
tissue does not have cross-cutting parabolic cracks.

Thus, simultaneously there are two processes of destruction. The first process is linear, which is caused by the translational movement of the projectile with the formation of the zone of hydrostatic compression of the material and formation of annular cracks on the outer bone plate along the edges of the gunshot fracture. The second process is angular, caused by the transfer of angular velocity from the projectile to the damaged bone with the formation of angular displacements of the damaged bone tissue (in the direction of rotation of the projectile), which leads to the formation of annular and radial bone cracks.

Reaching the surface of the inner bone plate, the median fissure forms radially divergent cracks, which are directed from the center to the periphery. At this moment, the edges of the radial fracture lines receive an angular acceleration from the rotation of the projectile. When the tensions in the damaged bone tissue reach critical values, the bone is destroyed, with formation of specific morphological signs.

The established mechanism of the formation of chips at the edges of a gunshot fracture, both from the outside and from the inner bone plate, allows the forensic expert not only to determine the direction of rotation of the projectile, but also the structural features of the weapon from which the shot was fired.

\section{Literature}

1. Гирголав СС. Огнестрельная рана. Ленинград: Воен.-мед. акад.; 1956. 331 с.

2. Давыдовский ИВ. Огнестрельная рана человека. Т.1. Москва: АМН СССР; 1952. 358 с.

3. Корнеевский ME. К вопросу о механизме образования конусообразного раневого канала в плоских костях при огнестрельных повреждениях. Сборник научных работ по судебной медицине и пограничным областям. 1955;2:106-9.

4. Kijewski H. Möglichkeiten zur bestimmung von kaliber, geschoßart und - geschwindigkeit aus der morphologie des schußkanals im schädelknochen. Arch Kriminol. 1979;164:107-21.

5. Попов ВЛ, Шигеев ВБ, Кузнецов ЛЕ. Судебно-медицинская баллистика. Санкт-Петербург: Гиппократ; 2002.656 с.

6. Янковский ВЭ, Шадымов АБ. Особенности входного огнестрельного повреждения на плоских костях черепа безоболочечной пулей при выстреле под углом 90 из малокалиберной винтовки ТОЗ-8 калибра 5,6 мм. Судебно-медицинская экспертиза. 1987;3:7-10.

7. Шадымов АБ. Особенности формирования огнестрельного входного пулевого повреждения костей свода черепа при выстрелах из некоторых видов нарезного оружия [автореферат]. Москва; 1988. 22 с.

8. Крюков ВН. Основы механо- и морфогенеза переломов. Москва: Фолиум; 1995. 232 с.

9. Леонов СВ, Дубровин ИА, Михайленко АВ, Дубровин АИ. Механизм формирования огнестрельного перелома. Медицинская экспертиза и право. 2013;5:39-43.

10. Опыт советской медицины в Великой Отечественной войне 1941-1945 г.г. Москва: Государственное издательство медицинской литературы; 1952. 32 тома. Т. 34. Патология огнестрельных ранений и повреждений. Общие данные по патологии огнестрельных ранений и повреждений; Смольянников АВ, Механизм действия огнестрельного снаряда; с. 17-54.

\section{References:}

1. Girgolav SS. Ognestrel'naya rana [Gunshot wound]. Leningrad: Voen.-med. akad.; 1956. 331 s. (in Russian)

2. Davydovskiy IV. Ognestrel'naya rana cheloveka [Human Gunshot Wound]. T.1. Moskva: AMN SSSR; 1952.358 s. (in Russian)

3. Korneevskiy ME. K voprosu o mekhanizme obrazovaniya konusoobraznogo ranevogo kanala v ploskikh kostyakh pri ognestrel'nykh povrezhdeniyakh [To the question of the mechanism of formation of a cone-shaped wound canal in flat bones with gunshot injuries]. Sbornik nauchnykh rabot po sudebnoy meditsine i pogranichnym oblastyam. 1955;2:106-9. (in Russian)

4. Kijewski H. Möglichkeiten zur bestimmung von kaliber, geschoßart und - geschwindigkeit aus der morphologie des schußkanals im schädelknochen. Arch Kriminol. 1979;164:107-21.

5. Popov VL, Shigeev VB, Kuznetsov LE. Sudebno-meditsinskaya ballistika [Forensic Ballistics]. Sankt-Peterburg: Gippokrat; 2002. 656 s. (in Russian)

6. Yankovskiy VE, Shadymov AB. Osobennosti vkhodnogo ognestrel'nogo povrezhdeniya na ploskikh kostyakh cherepa bezobolochechnoy puley pri vystrele pod uglom $90^{\circ}$ iz malokalibernoy vintovki TOZ-8 kalibra 5,6 mm [Specific features of inlet gunshot wound on the plane skull bones produced by uncoated bullet in case of shot at rignt angle from a small-bore gun toz-8 of 5.6 mm calibre]. Sudebno-meditsinskaya ekspertiza. 1987;3:7-10. (in Russian)

7. Shadymov AB. Osobennosti formirovaniya ognestrel'nogo vkhodnogo pulevogo povrezhdeniya kostey svoda cherepa pri vystrelakh iz nekotorykh vidov nareznogo oruzhiya [Features of the formation of a gunshot entrance bullet damage to the bones of the cranial vault during shots from some types of rifled weapons] [avtoreferat]. Moskva; 1988. 22 s. (in Russian)

8. Kryukov VN. Osnovy mekhano- i morfogeneza perelomov [Fundamentals of mechano- and morphogenesis of fractures]. 
червень, 2019 p.

Moskva: Folium; 1995. 232 s. (in Russian)

9. Leonov SV, Dubrovin IA, Mikhaylenko AV, Dubrovin AI. Mekhanizm formirovaniya ognestrel'nogo pereloma [The mechanism of the formation of a gunshot fracture]. Meditsinskaya ekspertiza i pravo. 2013;5:39-43. (in Russian)

10. Opyt sovetskoy meditsiny v Velikoy Otechestvennoy voyne 1941-1945 g.g. [The experience of Soviet medicine in the Great Patriotic War of 1941-1945] Moskva: Gosudarstvennoe izdatel'stvo meditsinskoy literatury; 1952. 32 toma. T. 34. Patologiya ognestrel'nykh raneniy i povrezhdeniy. Obshchie dannye po patologii ognestrel'nykh raneniy i povrezhdeniy [Pathology of gunshot wounds and injuries. General data on the pathology of gunshot wounds and injuries]; Smol'yannikov AV, Mekhanizm deystviya ognestrel'nogo snaryada [The mechanism of action of a firearm]; s. 17-54. (in Russian)

\section{МЕХАНІЗМ ФОРМУВАННЯ РОТАЦЙНИХ СКОЛІВ КОМПАКТНОГО ШАРУ ПО КРАЯХ ВОГНЕСТРІЛЬНОГО ПЕРЕЛОМУ ПЛАСКИХ КІСТОК}

Михайленко А.

Резюме. У відділенні судово-медичної криміналістики Київського міського клінічного бюро судово-медичної експер- тизи досліджено механізм формування ротаційних сколів компактного шару по краям вогнестрільного перелому пласких кіс- ток. Процес утворення тріщин був розглянутий на прикладі двох задач - задачі Герца і моделі Хілла-Джонсона. Встановлено, що в основе формування перелома лежить складний напружений стан і деформування матеріалу, що викликане поступаль- ним і обертовим рухами вогнестрільного снаряду.

Ключові слова: лабораторна діагностика, вогнестрільна зброя, вогнестрільний перелом, механізм утворення рота- ційних сколів, нарізи каналу ствола.

\section{MECHANISM OF FORMATION OF ROTARY COMPACT LAYER CHIPPING AT THE EDGES OF THE GUNSHOT FRACTURE OF FLAT BONES}

\footnotetext{
Mikhaylenko O.

Summary. Mechanism of rotation chips formation of a compact layer on the edges of the gunshot fractures of flat bones was studied. The process of cracking was considered by the example of two models - the Hertz model and Hill-Johnson model. It was found that the formation of a fracture is complex tension and deformation of the material, caused both by translational and rotational move- ments of a bullet.

Keywords: firearms, gunshot fracture, mechanism of rotary chipping, rifles of the barrel.
} 